\title{
Land use impact assessment in the construction sector: an analysis of LCIA models and case study application
}

\author{
Karen Allacker • Danielle Maia de Souza • Serenella Sala
}

Received: 19 December 2013 / Accepted: 1 July 2014 /Published online: 8 October 2014

(C) Springer-Verlag Berlin Heidelberg 2014

\begin{abstract}
Purpose Land use is a potentially important impact category in life cycle assessment (LCA) studies of buildings. Three research questions are addressed in this paper: Is land use a decisive factor in the environmental impact of buildings?; Is it important to include the primary land use of buildings in the assessment?; and How does the environmental performance of solid structure and timber frame dwellings differ when assessed by distinct available models for quantifying land use impacts? Methods This paper compares several operational land use impact assessment models, which are subsequently implemented in an LCA case study comparing a building constructed using timber frame versus a solid structure. Different models were used for addressing the different research questions.

Results and discussion The results reveal that contrasting decisions may be supported by LCA study results, depending on whether or not and how land use is included in the assessment. The analysis also highlights the need to include the building
\end{abstract}

Responsible editor: Holger Wallbaum

Electronic supplementary material The online version of this article (doi:10.1007/s11367-014-0781-7) contains supplementary material, which is available to authorized users.

K. Allacker $(\bowtie) \cdot$ D. Souza $\cdot$ S. Sala

European Commission Directorate General-Joint Research Centre, Institute for Environment and Sustainability, Ispra, Italy

e-mail: karen.allacker@asro.kuleuven.be

Present Address:

K. Allacker

Department of Architecture, KU Leuven, Kasteelpark Arenberg 1, 3001 Leuven, Belgium

Present Address:

D. Souza

Department of Energy and Technology, Swedish University of Agricultural Sciences, Lennart Hjelms väg 9, 75007 Uppsala, Sweden land footprint in the assessment and to better distinguish building locations in current land use impact assessment models. Conclusions Selecting land use assessment models that are most appropriate to the goals of the study is recommended as different models assess different environmental issues related to land use. In general, the combination of two land use assessment methods for buildings is recommended, i.e. soil organic matter (SOM) of Milà i Canals and Eco-indicator 99.

Keywords Construction · Impactassessment $\cdot$ Land use $\cdot$ Life cycle assessment $\cdot$ Resource depletion

\section{Introduction}

The building sector is amongst the most cross-cutting industrial sectors. Transition towards sustainable building hence requires harmonisation of and interaction between diverse topics from security of the citizen to environmental impact, human health and resource efficiency. Several European Commission (EC) policies recognise the relevance of considering environmental impacts of buildings from a life cycle perspective with respect to resource efficiency, construction and demolition waste, and energy (EC 2009; EC 2010a, b; EC 2011a; EC 2012). In order to effectively accommodate these issues, the European EN15804 (CEN 2011) and EN15978 (CEN 2012) standards recommend the use of Life cycle assessment (LCA) for evaluation of construction products and buildings.

LCA is a decision support methodology for assessing potential impacts that may occur during the life cycle of a product, considering a variety of resource use, human health and environmental impact categories. EN15804 and EN15978 require consideration of the following environmental impact categories: global warming, ozone depletion, acidification of soil and water, eutrophication, photochemical ozone creation 
and depletion of abiotic resources. In addition, ten criteria related to resource use, three for waste and four criteria for output flows (i.e. re-use, recycling, energy recovery and energy) are also included. On this basis, it would appear that priority impact areas (resources, waste and energy) identified in the aforementioned policy documents are sufficiently accommodated in analyses based on these standards.

Although land use is a potentially relevant environmental impact category for life cycle-based evaluations of the construction sector, it is currently not included in existing national and European norms and standards such as the EN15804 and EN15978, NEN 8006 (NEN 2004) and NF P 01-010 (AFNOR 2004). Consideration of land use related to resource extraction, production, transport and end-of-life treatment of building products is similarly neglected in widely used sustainability certification systems of buildings such as the BRE Environmental Assessment Method (BREEAM) (BRE 2007, 2013), Leadership in Energy and Environmental Design (LEED) (USGBC 2013) and the German Sustainable Building Council (DGNB 2013) system. Hence, these certification systems only consider land use in a limited sense (land use of the building itself in only specific cases). Land is, however, essential for the provision of ecosystem services, such as food and biomass production, and for the maintenance of key environmental functions such as soil functions and carbon storage (EEA 2010). It is also a finite resource. How land is used is a critical determinant of environmental change and impacts on ecosystem quality (such as biodiversity) and function. Several European policies such as the Soil Thematic Strategy (European Commission- EC 2006) and the Biodiversity Strategy to 2020 (EC 2011b) explicitly recognise land use change as figuring amongst the most important environmental concerns. The Roadmap for a ResourceEfficient Europe (EC 2011a) also considers improved land use management as a key contributor to achieving more sustainable use of resources.

Additionally, although LCA is a widely used methodology to assess the environmental impact of buildings (Allacker et al. 2011; Allacker 2012; Asif et al. 2007; Feist et al. 2001), the main focus of LCA studies of buildings has been on energy-related impacts (Passivhaus Institut 2006; Helgeson and Lippiatt 2009; Nemry et al. 2010; Valderrama et al. 2012; Zabalza Bribián et al. 2009). Even in more comprehensive LCA-based evaluations, land use is not included. For example, Nemry et al. (2010) review the environmental profiles of 72 building typologies in the European Union (EU) in terms of primary energy use, and acidification, eutrophication, global warming, ozone layer depletion and photochemical ozone creation potentials. Similarly, Werner and Richter's (2007) review of the life cycle environmental impact of building materials - which demonstrates that wood products tend to have a lower environmental impact compared to functionally equivalent products composed of other materials -takes into account a broad suite of impact categories. Land use is not comprehensively considered in either of these analyses.

An environmental cost evaluation by Allacker (2010) and Allacker et al. (2011) underscores the importance of considering land use in order to increase the robustness and credibility of LCA studies in the building sector. However, a recent evaluation of existing methodologies for impact assessment in LCA suggested that current models for quantifying land use are subject to considerable uncertainty (Werner and Richter 2007; EC-JRC 2011). In part, this is due to the multifunctional nature of land and the various possible impact pathways that can be considered (Allacker 2010).

Amongst other impact categories (Finnveden et al. 2009), land use modelling in LCA has been the subject of considerable research. A subset of available land use impact assessment models were summarised and reviewed in the International Reference Life Cycle Data System (ILCD) Handbook (EC-JRC 2011). The ILCD review includes models covering the main attributes of Ecosystem Quality that are affected by land use: biodiversity, biotic production potential and ecological soil quality. ILCD provides an overview of several midpoint (expressing potential impacts early in the cause-effect chain) and endpoint (expressing the damages further along the cause-effect chain) models and indicators, summarising their main characteristics. Recommendations are made as to their suitability for the use based on a set of preselected criteria (Electronic supplementary material, Table S.1). Although the endpoint indicators are easier to interpret, their associated level of uncertainty may be higher due to an increase in modelling, scenario and parameter complexity (Bare et al. 2000). Beside the models reviewed and recommended in the ILCD (Milà i Canals et al. 2007), some other models also contributed to the current status of land use modelling (Bluemer and Kylaekorpi 1998; Köllner 2003; Köllner et al. 2013b; Köllner and Geyer 2013; Michelsen 2008; Müller-Wenk 1998; Saad et al. 2013; Souza 2010; Souza et al. 2013; Weidema and Lindeijer 2001).

This paper focuses on the quantification of land use impacts in LCA of buildings. A distinction is made between two types of interventions: land transformation and land occupation. Land transformation (also called land use change or land conversion) occurs when there is a change in the land use type in a certain area (for example, from forest to organic meadow) that leads to a transformation impact. Land occupation takes place when a specific land use type is maintained which leads to a delay in the recovery of land to its potential natural state. Transformation and occupation may lead to reversible or irreversible (also called permanent) impacts.

Our study deals with both the building "footprint" or land use surface transformed and occupied by the building itself (primary land use) and the land transformation and occupation associated with the extraction of resources, production of building materials, heating and maintenance of buildings, 
and end-of-life (EOL) treatment of building products, including all necessary transport activities. Three main research questions are addressed: (1) Is land use a decisive factor in the environmental impacts of buildings? (AAVV 2005); (2) Is it important to include the primary land use of buildings in the assessment? (AFNOR 2004); and (3) How does the environmental performance of similar solid structure and timber frame dwellings differ when assessed by distinct available models for quantifying land use impacts? (Allacker 2010)

\section{Materials and methods}

The three research questions were analysed based on the same case study, as described in the subsequent section. Different life cycle environmental impact assessment methods were used for the different research issues and are further elaborated in Section 2.2.

\subsection{Case study}

The case study is a flat-roofed, single-storey, single-family detached house in Belgium (Fig. S.1, Electronic supplementary material). The house has a floor area of $150 \mathrm{~m}^{2}$ and a heated (protected) volume of $370 \mathrm{~m}^{3}$. The life span of the dwelling is assumed to be 60 years for the calculation of the energy demand and cleaning, maintenance and replacement activities. For the calculation of the land use impacts from occupation and transformation, the Ecoinvent default use periods for the different land use classes were assumed. The thermal compactness of the house (i.e. ratio of the volume and the building envelope surface) is $0.967 \mathrm{~m}$. The house is assumed to be newly built in compliance with the current (2012) building regulations in Belgium regarding energy performance (i.e. insulation value, energy use, ventilation and overheating) (VEA 2012). Two different construction techniques are compared: a solid structure and a timber frame structure. The solid structure is composed of cavity walls of clay building blocks (and brick veneer as external finishing), inner walls of clay building blocks and a flat roof consisting of a precast hollow reinforced concrete slab. The timber frame is composed of a wood skeleton filled with rock wool insulation (and a brick veneer as external finishing) and a flat roof composed of wooden joists and cross beams. The composition of the most important building elements (floor on grade, inner and outer walls and flat roof) is presented in the Electronic supplementary material, Table S.3. The windows have thermally improved double glazing ( $U$ value of $1.1 \mathrm{~W} / \mathrm{m}^{2} \mathrm{~K}$ ). The solid structure house has aluminium window frames with a $U$ value of $1.4 \mathrm{~W} / \mathrm{m}^{2} \mathrm{~K}$, while the timber-framed house consists of insulated timber window frames with a $U$ value of $0.74 \mathrm{~W} /$ $\mathrm{m}^{2} \mathrm{~K}$. The air-tightness of both dwellings is assumed to be identical and equals 0.6 air changes per hour. Table S.2
(Electronic supplementary material) provides a summary of the energy-related requirements and characteristics of each building.

The LCA study covers all life cycle stages, from extraction of resources to end-of-life. Generic life cycle inventory data were taken from the Ecoinvent database (version 2.2) (Ecoinvent 2012). The datasets were adapted to improve the representativeness for the Belgian context, i.e. by replacing Swiss electricity mix and transport means to the European ones (Electronic supplementary material, Table S.4). For the transport and end-of-life scenarios, information from previous research surveys (Electronic supplementary material, Table S.5, Table S.12 and Table S.13) was used, while cleaning, maintenance and replacement scenarios (Electronic supplementary material, Table S.6) were based on literature studies (Allacker et al. 2011). Energy calculations for heating were performed based on the Energy Performance of Buildings Directive in Flanders (EPBD) and for sanitary hot water based on the Passive House Platform method (AAVV 2005; Feist et al. 2001; Passivhaus Institut 2006). The results of the energy calculations are summarised in the Electronic supplementary material (Table S.7 and Table S.8). The functional unit equals a $1 \mathrm{~m}^{2}$ floor area, heated to an average daily temperature of $18{ }^{\circ} \mathrm{C}$, per year. It is assumed that there is no cooling. A detailed description of the functional unit, system boundaries and life cycle inventory can be found in the Electronic supplementary material, Tables S.9-S.10.

\subsection{Methodological approaches for addressing land use} impacts under different research questions

Different operational land use impact assessment models were used to answer each of the three research questions. The first research question, i.e. whether land use is a decisive factor in the environmental impacts of buildings, was addressed by analysing the importance of land use as an impact category (i.e. as compared to other impact categories) in a multi-criteria LCA. Three endpoint methods, Eco-Indicator 99 (EI99) (Goedkoop and Spriensma 2000), ReCiPe (Goedkoop et al. 2012) and IMPACT 2002+ (Humbert et al. 2012; Jolliet et al. 2003) were applied to evaluate the timber frame and solid structure dwellings, first including then subsequently excluding assessment of land use. For EI99 and ReCiPe, the normalisation factors according to the 'hierarchist' profile and average weighting factors were used (see Table 1). The resulting six single scores allowed for evaluating if land use is a decisive factor or not in a comprehensive LCA of buildings. In this analytical step, the building was assumed to be built on arable land. As the purpose was to roughly estimate the relative importance of land use in a multi-impact category life cycle analysis evaluated at endpoint level, it only comprises the production stage (production of the materials) and energy use during the use stage of the building, including primary 
Table 1 Comparison of the timber frame and solid structure building with EI99, ReCiPe and IMPACT 2002+; with and without the assessment of land use, expressed as a single score per square meter floor

\begin{tabular}{llll}
\hline & Timber frame & & Solid \\
\hline EI99 $^{\mathrm{a}}(\mathrm{Pt})$ & 43.31 & $>$ & 41.74 \\
EI99 without land use (Pt) & 36.40 & $<$ & 37.61 \\
ReCiPe $^{\mathrm{b}}(\mathrm{Pt})$ & 77.13 & $>$ & 71.94 \\
ReCiPe without land use (Pt) $_{\text {IMPACT 2002+ (version 2.1) }}^{\mathrm{c}}(\mathrm{Pt})$ & 64.45 & $<68.12$ \\
IMPACT 2002+ without land use $(\mathrm{Pt})$ & 34.82 & $<36.15$ \\
\hline
\end{tabular}

${ }^{a}$ Hierarchist perspective for normalisation for Western Europe (population considered $380,000,000$ ) for each area of protection (human health $(\mathrm{HH})=8.76 \times 10^{-3} \mathrm{DALY} /$ person year or $3.33 \times 10^{6} \mathrm{DALY} /$ year; quality of ecosystems $(\mathrm{QE})=5.72 \times 10^{3} \mathrm{PDF} \cdot \mathrm{m}^{2} \cdot$ year/person year or $2.17 \times 10^{12}$ $\mathrm{PDF} \cdot \mathrm{m}^{2} \cdot$ year/year; and depletion of resources $(\mathrm{DR})=7.55 \times 10^{3} \mathrm{MJ} /$ person year or $2.87 \times 10^{12} \mathrm{MJ} /$ year $)$ and average weighting set $(\mathrm{HH}=400$; $\mathrm{QE}=400$; and $\mathrm{DR}=200$ )

${ }^{\mathrm{b}}$ Hierarchist perspective for normalisation for Europe (population considered $728,000,000)$ for each area of protection $\left(\mathrm{HH}=2.02 \times 10^{-2}\right.$ $\mathrm{DALY} /$ person year or $1.47 \times 10^{7} \mathrm{DALY} /$ year; $\mathrm{QE}=1.81 \times 10^{-4}$ species . year/person year or $1.32 \times 10^{5}$ species $\cdot$ year/year; $D R=3.08 \times 10^{2} \$ /$ person year or $2.24 \times 10^{11} \$$ year $)$ and average weighting set $(\mathrm{HH}=\mathrm{QE}=400$; $\mathrm{DR}=200$ )

${ }^{\mathrm{c}}$ Normalisation factors for Western Europe (population considered $431,000,000)$ for each area of protection $\mathrm{HH}=7.1 \times 10^{-3} \mathrm{DALY} / \mathrm{Pt}$ (=DALY/person year); QE $=1.37 \times 10^{4} \mathrm{PDF} \cdot \mathrm{m}^{2} \cdot \mathrm{year} / \mathrm{Pt}\left(=\mathrm{PDF} \cdot \mathrm{m}^{2}\right.$. year/person year) or $5.90 \times 10^{12} \mathrm{PDF} \cdot \mathrm{m}^{2} \cdot$ year/year; climate change (CC) $=9.90 \times 10^{3} \quad \mathrm{~kg} \mathrm{CO}_{2}$ into air/Pt ( $=\mathrm{kg} \mathrm{CO}_{2}$ into air/person year); and $\mathrm{DR}=1.52 \times 10^{5} \mathrm{MJ} / \mathrm{Pt}(=\mathrm{MJ} /$ person year $)$ and weighting factors $(\mathrm{HH}=$ $\mathrm{QE}=\mathrm{CC}=\mathrm{DR}=1$ )

land use. This seems justified because previous research suggests that these two stages are the most important for new residential buildings (according to current building standards in Belgium) (Allacker 2010).

The same assessment methods were used for the second research question, focusing on the relative importance of primary versus secondary land use. The three endpoint methods were applied for different scenarios regarding the location of the new building assuming five alternative land use types (i.e. agriculture land, arable land, pasture and meadow, dump site and an intensive forest). Two types of building were furthermore analysed (i.e. continuously built (at least $80 \%$ of the area occupied is considered to be sealed) versus discontinuously built (less than $80 \%$ of the total area is considered to be sealed)). For each of these scenarios, the land use impact was investigated through a detailed analysis of the contribution of (a) transformation from the previous land type, (b) transformation to the new land use type/class and (c) occupation of the new type of land use type/class.

The third research question, i.e. how does the environmental performance of similar solid structure and timber frame dwellings differ when assessed by distinct available models for quantifying land use impacts?, was analysed based on a comparative LCA of the solid structure and timber frame dwelling using the 14 ILCD-recommended impact categories and models (EC-JRC 2011). Table S.14 (Electronic supplementary material) provides an overview of the assessment models for each impact category with the corresponding indicator. Additionally, a more in-depth analysis of the land use impact was undertaken by comparing the results with those obtained using other land use impact assessment models. Five alternative models were used: ReCiPe midpoint (Goedkoop et al. 2012), EPS2000 (Steen 1999), EI99 endpoint (Goedkoop and Spriensma 2000), ReCiPe endpoint (De Schryver and Goedkoop 2009) and Swiss Ecoscarcity (Frischknecht et al. 2008). These were selected because they were considered in the analysis undertaken to develop the ILCD recommendations for life cycle impact assessment (LCIA) methods and models, and because of their availability in SimaPro software (Pre Consultants 2012). The considered impact assessment models for the land use sensitivity analysis are summarised in the Electronic supplementary material (Table S.15), including the sources of the characterisation factors used. For this analysis, all life cycle stages of the building were considered. Moreover, we added, at the end of this paper, some comments on models recently developed and not yet operational, but which introduced substantial improvements to land use modelling in LCIA.

\section{Results}

3.1 The relative importance of land use in a comprehensive LCA of buildings

The LCA of the timber frame and solid structure building reveals that, when land use is not included, the timber frame dwelling has a better overall (i.e. single score) environmental performance than the solid structure building, according to all three of the endpoint methods applied (Table 1), revealing that land use plays an important role on impacts from the timber frame. However, if land use impacts are considered, the solid structure building scores better according to EI99 and ReCiPe, while the timber frame dwelling has apparently lower impacts according to the IMPACT $2002+$ method. The minor importance of land use in the IMPACT 2002+ method (0.9 and $0.1 \%$ for the timber frame and solid structure building, respectively) explains this difference. A more detailed look at IMPACT $2002+$ clarifies that it does not take into account land transformation impacts. As it is explained below, this is not, however, the primary reason for the apparently small contribution of land use in the overall environmental score. Furthermore, IMPACT 2002+ takes the characterisation factors for land occupation directly from EI99, which means that the same impact of land use is accounted for. However, IMPACT $2002+$ uses different normalisation and weighting 
factors than EI99, which results in a small contribution of land use in the overall score. This is illustrated in Table 2.

A further analysis of the inventory and impact assessment results for land use clarified that land occupation is contributing most to the impact, while land transformation has only a minor impact. This is mainly due to either the absence of characterisation factors for land transformation (as in IMPACT 2002+) or due to the attribution of zero values for transformations from natural to natural (e.g. forest to forest, intensive) land use types. More specifically, the 'flow' 'occupation, forest, intensive, normal' ('forest, intensive' in Köllner et al. (2013a)), representing harvest of softwood used for the structure of the flat roof and hardwood used for timber frame windows led to the highest impact. As the flat roof contributed most to the impact due to 'occupation, forest, intensive, normal' ( $42 \%$ ), this element was analysed in more detail for the three methods (Table 2). The results clearly indicate that the three methods assign very different single score impacts. This is largely due to a difference in normalisation and weighting factors between the methods. For example, comparing the resulting single scores for IMPACT 2002+ and EI99, the damage assessment results are equal because both models apply the same characterisation factors for land occupation (Table 2). Due to differences in normalisation (for EI99, one order of magnitude smaller) and weighting (for EI99, two orders of magnitude higher), however, the resulting single score for these two models differs by three orders of magnitude.

The analysis hence confirms that land use can be a decisive factor when comparing the life cycle environmental impact of a timber frame and solid structure building (Table 1). The analysis moreover highlights the importance of choosing an assessment method that covers the goal of the study (Table 2).

\subsection{Primary versus secondary land use}

The results of the land use impact due to primary land use are summarised in Table 3 for each of the three impact assessment methods employed. For comparative purposes, the impact due to secondary land use is also included in the table for both the timber frame and solid structure buildings. Based on EI99, the impact of primary land use is higher than that of secondary land use (i.e. 3.63-6.04 compared to $0.5-3.27 \mathrm{Pt} / \mathrm{m}^{2}$ floor). According to the ReCiPe results, this is only true for the solid structure building (i.e. 2.74-6.98 compared to $1.08 \mathrm{Pt} / \mathrm{m}^{2}$ floor), while the opposite is true for the timber frame dwelling (i.e. 2.74-6.98 compared to $9.94 \mathrm{Pt} / \mathrm{m}^{2}$ floor). According to IMPACT $2002+$, the impact due to secondary land use for both building types and for all locations is higher (i.e. 0.0042 compared to $0.03-0.31 \mathrm{Pt} / \mathrm{m}^{2}$ floor).

IMPACT $2002+$ only assesses occupation impacts, which explains the unimportance of the location of the newly built dwelling for the study results. This is a significant limitation of the method, which should be considered when choosing whether or not to use it in a specific context. For example, when a study is performed to investigate the environmental impacts related to choice of location for a new building, IMPACT 2002+ should not be employed.

$\mathrm{ReCiPe}$ assigns a higher impact when the house is built on forest land compared to the other land types (the impact is more than double). This is because, although ReCiPe takes into account land transformation, it does not differentiate between land use conversions from a natural to a natural land use type such as transformation from forest to shrubland, nor from a non-natural to a non-natural land use type such as from agriculture to urban. For these transformation processes, the characterisation factors are zero $(\mathrm{CF}=0)$. As observed in Table 3, the land use change 'from forest intensive' is the only transformation to which a $\mathrm{CF}$ is attributed $\left(\mathrm{CF}_{\text {trans }}=130 \mathrm{PDF}\right.$. $\mathrm{m}^{2} \cdot$ year or $\mathrm{CF}_{\text {trans }}=1.92 \times 10^{-6}$ species $\cdot$ year). It is important to understand this limitation of the method when analysis of building location is important in an LCA study.

Amongst the three methods considered, EI99 provides the greatest differentiation between the different land use categories. In comparison to IMPACT $2002+$, it allows consideration of impacts of transformation, and in comparison to ReCiPe, it distinguishes transformations between two natural (or closeto-natural) or non-natural land use types. According to the results generated using EI99, the highest impact occurs when the house is built on agricultural land - the only land type of the four considered that does not produce a negative impact due to 'land transformation from'. This is because EI99

Table 2 Flat roof - 'occupation, forest, intensive, normal': comparison methods per square meter floor area

\begin{tabular}{llll}
\hline & EI99 & ReCiPe & IMPACT 2002+ \\
\hline Inventory $\left(\mathrm{m}^{2} \mathrm{a}\right)$ & 157 & 157 & 157 \\
Damage assessment & $17.27 \mathrm{PDF} \cdot \mathrm{m}^{2} \cdot$ year & $1.88 \mathrm{E}-06$ species $\cdot \mathrm{year}^{\mathrm{a}}$ & $17.27 \mathrm{PDF} \cdot \mathrm{m}^{2} \cdot \mathrm{year}$ \\
Normalised & 0.00302 & 0.0104 & 0.00126 \\
Single score $(\mathrm{Pt})$ & 1.21 & 4.16 & 0.00126 \\
Percentage of total building impact & 2.65 & 5.11 & 0.34 \\
\hline
\end{tabular}

${ }^{\mathrm{a}}$ The resulting damage assessment value for ReCiPe in species $\cdot$ year corresponds to the value of $127 \mathrm{PDF} \cdot \mathrm{m}^{2} \cdot$ year, considering a total number of species in the world equal to $1,604,000$ and a damage area surface, in square meter, of $1.084 .10^{14}$ 
Table 3 Building - land use impact (per $\mathrm{m}^{2}$ floor) due to primary land use of the building assuming a life span of 60 years, for several scenarios, expressed as follows: $\mathrm{T}$ (total) (TF (transformation from) $+\mathrm{TT}$ (transformation to) $+\mathrm{O}$ (occupation))

\begin{tabular}{llll}
\hline Urban, discontinuously built & EI99 $(\mathrm{Pt})^{\mathrm{a}}$ & ${\text { Recipe }(\mathrm{Pt})^{\mathrm{a}}}$ & ${\text { IMPACT 2002+ }(\mathrm{Pt})^{\mathrm{a}}}^{\mathrm{a}}$ \\
\hline From agriculture & $6.04\left(0^{\mathrm{b}}+2.01+4.03\right)$ & $2.74\left(0^{\mathrm{c}}+0^{\mathrm{c}}+2.74\right)$ & $0.0042\left(0^{\mathrm{b}}+0^{\mathrm{b}}+0.0042\right)$ \\
From arable (sub-category of agriculture) & $3.63(-2.4+2.01+4.03)$ & $2.74\left(0^{\mathrm{c}}+0^{\mathrm{c}}+2.74\right)$ & $0.0042\left(0^{\mathrm{b}}+0^{\mathrm{b}}+0.0042\right)$ \\
From pasture and meadow & $3.9(-2.14+2.01+4.03)$ & $2.74(0+0+2.74)$ & $0.0042\left(0^{\mathrm{b}}+0^{\mathrm{b}}+0.0042\right)$ \\
From dump site, inert material landfill & $4.28(-1.76+2.01+4.03)$ & $2.74\left(0^{\mathrm{c}}+0^{\mathrm{c}}+2.74\right)$ & $0.0042\left(0^{\mathrm{b}}+0^{\mathrm{b}}+0.0042\right)$ \\
From forest intensive & $5.81(-0.231+2.01+4.03)$ & $6.98(4.24+0+2.74)$ & $0.0042\left(0^{\mathrm{b}}+0^{\mathrm{b}}+0.0042\right)$ \\
Secondary land use solid/timber frame & $0.50 / 3.27$ & $1.08 / 9.94$ & $0.03 / 0.31$
\end{tabular}

a A similar analysis was made for 'urban, continuously built', resulting in the following:

- EI99: a higher impact due to occupation, i.e. 4.82 Pt instead of 4.03 Pt, and transformation to, i.e. 2.41 Pt instead of 2.01 Pt

- ReCiPe: both land uses have identical CFs for occupation, while the CFs for transformation are zero

- IMPACT 2002+: a higher impact due to occupation, i.e. $0.00504 \mathrm{Pt}$ instead of $0.0042 \mathrm{Pt}$

${ }^{\mathrm{b}}$ No characterisation factor available for this transformation

${ }^{\mathrm{c}}$ For this transformation, $\mathrm{CF}=0$

subdivides the land category 'agriculture' into different subcategories, of which 'arable' is one. The method does not provide characterisation factors for the land use categories which are further subdivided (only the subdivision was assigned characterisation factors). It can hence be concluded that it is important to check the structure of the different land use categories of the environmental impact assessment method selected in order to verify that these are appropriate in the context of a given study.

Of the three methods considered, ReCiPe is the only one that does not differentiate between the impacts of continuously and discontinuously built urban land. Both IMPACT 2002+ and EI99 assign a higher land use impact to continuously built land.

Based on the analysis of this specific building typology (i.e. a single-family one-level detached dwelling), the order of magnitude of the impact of primary land use is similar to that of secondary land use for the building. It should be noted, however, that this conclusion is specific to the case study considered and cannot be generalised to all buildings. Because the single-storey building in the case study occupies a relatively high amount of land per square meter floor area, the impact of the primary land use is correspondingly higher than it would be for more densely built multi-storey buildings. For example, for an apartment building with ten floors with the same useful floor area per apartment, the impact due to primary land use of the building per square meter floor area will be only $1 / 10$ th of that of the current case study. It can, therefore, be concluded that considering the primary land use of the building is very important for low density buildings but not necessarily so for other building typologies. The relevance of primary land use for high-density buildings in more natural areas needs further investigation and, even more importantly, for the comparison of design alternatives with different densities (see Electronic supplementary material, Fig. S.2, for an illustrative example of the influence of building typology on primary land use impact of buildings). From an urban planning perspective, density may be an important component of reducing impacts due to primary land use of buildings.

\subsection{Comparative LCA of solid structure versus timber frame dwellings}

The comparative LCA of the solid structure and timber frame dwellings using ILCD-recommended models (EC-JRC 2011) shows that the timber frame dwelling has a lower life cycle impact for all impact categories other than land use, for which both dwellings perform similarly (Fig. 1). A significant difference of more than $20 \%$ is observed for depletion of minerals and fossil fuels. This is largely due to the different impacts of the two structural systems that are attributable to their characteristic elements and supporting life cycle stages. For example, the different window frames (i.e. aluminium versus timber) respectively used in the compared structures were largely responsible for differences in impacts at the production stage, while differences in the material properties of the inner and outer walls and the flat roof between the two structures resulted in different transportation-related impacts. For land use, in particular, few differences could be observed when using the ILCD-recommended soil organic matter (SOM) model from Milà i Canals et al. (2007) (Fig. 1).

The results of the sensitivity analysis of the land use impact category modelling reveals that the environmental performance of the timber frame dwelling is worse (i.e. with a higher impact ranging from 4 to $891 \%$ ) than of the solid structure dwelling regardless of which of the six considered impact assessment models is applied (Fig. 2). The comparatively higher impact is mainly due to differences in the production stage of building materials for the timber compared to the 
Fig. 1 Relative comparison of the life cycle environmental impact results of the solid structure and timber frame dwelling using the ILCD recommended methods, including land use assessment according to Milà i Canals

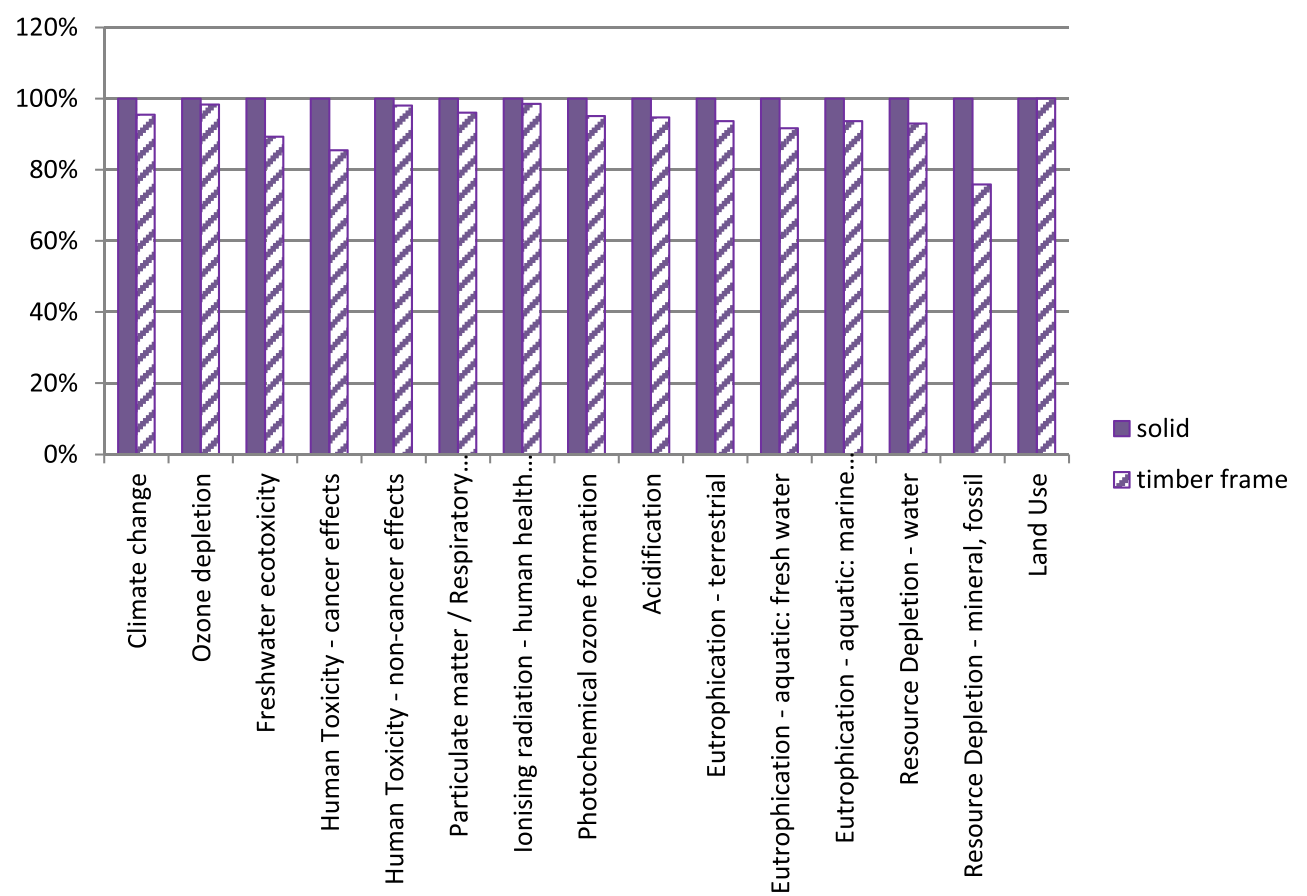

solid structure building, as well as the replacement of materials that are required over time.

The outer walls, inner walls and windows lead to a higher land use impact in the production stage for the timber frame compared to the solid structure dwelling, regardless of the impact assessment model applied. The flat roof is the element that contributes most to the land use impact during the production stage of the timber frame dwelling, except for the results obtained when using the SOM method of Milà i Canals et al. (2007). The foundations, floor on grade and technical services are the elements, which contribute most to the land use impact of the solid structure building for all methods other than the 'wood growth capacity' of the EPS2000 method (i.e. refers to a midpoint impact category which considers the reduction in the capacity of wood growth (in $\mathrm{kg}$ ), contributing to the overall 'Ecosystem Production Capacity' damage category), which indicates a higher growth capacity for the solid structure elements.

Due to its high contribution to land use impacts in the production of the timber frame building, the flat roof was analysed in more detail for both the solid structure and timber frame dwelling (Electronic supplementary material, Figs. S.3 and S.4). For the timber frame dwelling, the joists and cross beams in the flat roof contribute most to land use impacts regardless of the land use impact assessment model applied. For the roof of the solid structure building, the precast hollow reinforced concrete slab is most important. The latter, however, has a much lower land use impact compared to the joists and cross beams for all indicators of land use except SOM (where impacts are similar).

Fig. 2 Sensitivity analysis of the land use life cycle environmental impact of the solid structure (SOL) and timber frame (TF) dwelling: contribution of the different life cycle stages and processes

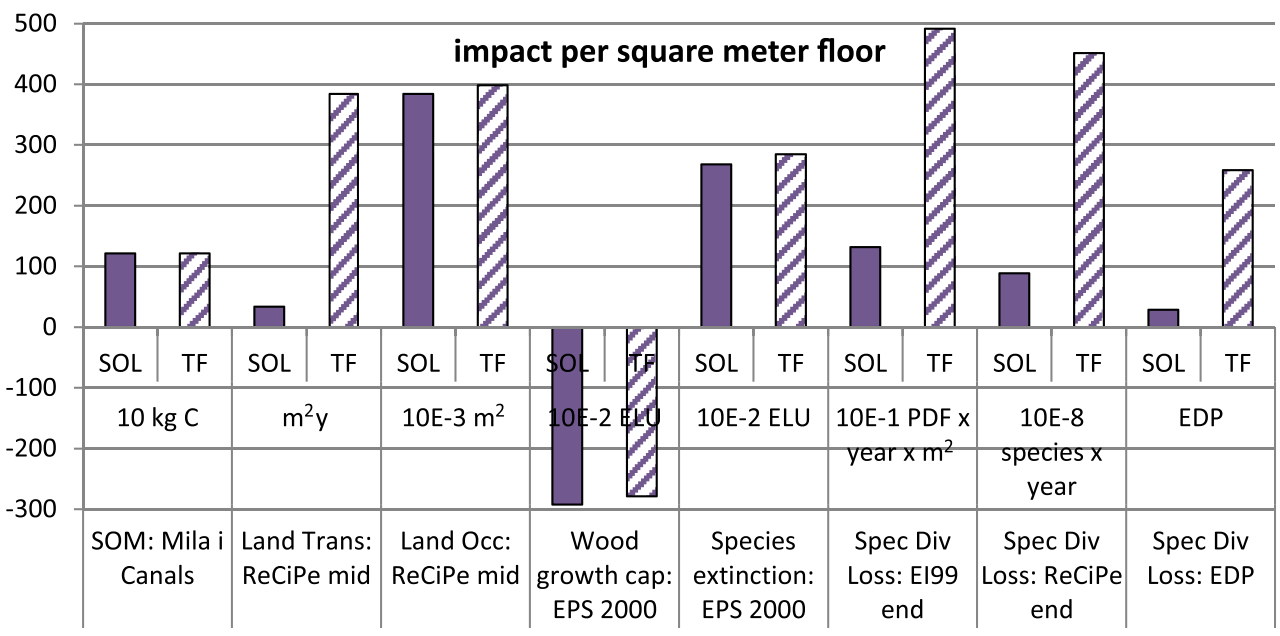


Despite this general consistency in assessment results across the methods applied, the degree of difference in estimated impacts between the two alternative flat roofs is actually highly variable. The apparent difference is smallest when using the SOM method (6\% higher impact for the joists and cross beams compared to the hollow reinforced concrete slab) and largest for the EDP method (14,8 \%).

With respect to soil carbon change, the mining of gravel contributes most to the land use impact of the concrete roof slab. More specifically, the land transformation associated with the extraction of gravel is largely responsible for the impact. This is followed by the production of unalloyed steel and Portland cement. For both, again, the land transformation for the mineral extraction site contributes most to the land use impact. A closer look clarifies that the high score is due to the influence of both the characterisation factors used and the amount of materials needed. For $1 \mathrm{~m}^{2}$ of roof slab, we assumed $0.113 \mathrm{~m}^{3}$ of concrete, which consists of $213 \mathrm{~kg}$ of gravel. For $1 \mathrm{~kg}$ of gravel, $0.0000288 \mathrm{~m}^{2}$ of land is transformed to mineral extraction site. With a characterisation factor for the flow 'Transformation, to mineral extraction site' of $7.5 \times 10^{3} \mathrm{~kg} \mathrm{C}$, this results in a land use impact of $46.13 \mathrm{~kg}$ $\mathrm{C} / \mathrm{m}^{2}$ roof. For the roof slab of joists and beams, the sawn timber contributes most to the land use impact. Land occupation (of different types) is responsible for $36 \%$ of the land use impact, with the main contribution from 'Occupation traffic area, road embankment' (33\%). Land transformation (different types) is responsible for $64 \%$, due to two flows: 'Transformation to traffic area, road embankment' (85\%) and 'Transformation to mineral extraction site' $(25 \%)$.

\section{Conclusions and recommendations}

Based on the implementation of three widely used endpoint LCIA methods, Eco-Indicator 99, ReCiPe and IMPACT $2002+$, land use was identified as a decisive factor in determining the apparent environmental preference of a singlestorey, single-family timber frame versus solid structure dwelling. It is hence recommended to include the land use impact category in LCA studies of buildings. Due to the importance of the normalisation and weighting factors used in endpoint LCIA methods, these factors must be carefully selected and transparently communicated. Currently, it is a common practice to only consider secondary land use in LCA studies of buildings. However, our analysis revealed the importance of also including primary land use. This will be particularly important for differentiating between the land use impacts of low- versus high-density developments.

As existing impact assessment methods for land use are highly heterogeneous, the choice of method should be based on consideration of the specific features of alternative methods and should be carefully matched with the goals and scope of the LCA study. Of the three endpoint methods considered, Eco-Indicator 99 was identified as the most comprehensive. IMPACT $2002+$ does not consider impacts from transformation of land, which may influence the species number in a given area. ReCiPe does not distinguish impacts that may occur due to transformations between two different natural or non-natural land use types. In the case of the latter, this effectively means that the biodiversity change resulting from a transformation from an agricultural field into an urban area, for example, is not taken into account. The same is true for a conversion from a primary forest to a managed forest, with intensive use (forest, intensive), for which ReCiPe assigns a characterisation factor of zero. More refined differentiation is hence recommended for the endpoint methods applied with regard to transformation characterisation factors. In the three abovementioned methods, no differences are, for example, assigned amongst defined land use subcategories, such as forest, forest extensive and forest intensive. This means that a natural, primary forest and a managed forest, with intensive use, are assigned the same loss of species diversity. Moreover, characterisation factors in the considered endpoint methods that consider land transformation (i.e. Eco-Indicator 99 and $\mathrm{ReCiPe}$ ) only result in a significant impact for land transformation if a building is located in a forest, again suggesting a need for further refinement. This is particularly needed in the building sector in light of the relevance of this kind of transformation. For example, in EU, soil losses by sealing through infrastructure and buildings are at a pace of, e.g. 120 ha per day in Germany, 35 ha per day in Austria (Jones et al. 2012). Urban sprawl is in direct competition with agricultural land uses and is threatening valuable agricultural soils all over Europe.

Based on the application of the ILCD-recommended midpoint models for the 14 impact categories to the case study, the depletion of minerals and fossil fuels is the only impact category for which a significant difference between the solid structure and timber frame dwelling (lower impacts) is observed. However, depletion of resources other than minerals and fossil fuels such as timber, sand, clay and gravel is not considered in the underlying models of the ILCD impact categories. It is hence recommended to add in future, updated versions of these models as they may be important to LCIA results.

Using the SOM (soil organic matter) method of Milà i Canals et al. (2007), a significant difference between the impacts of the two structures was not observed. In contrast, application of alternative land use LCIA models consistently indicated a higher land use impact for the timber frame dwelling. This result suggests that, although the two structures may not have a significantly different impact in terms of changing the soil carbon content, they do have significant different impacts on biodiversity loss due to the land transformations and occupations associated with the building life cycle. On 
this basis, it is recommended to implement at least one of these models for assessing biodiversity loss in addition to the SOM method in LCA studies of buildings and construction products. This recommendation is consistent with the ILCD recommendation with respect to the use of SOM for the impact assessment of land use (i.e. a level III recommendation, which means that the method is to be applied with caution and to be subject to sensitivity analysis with other models/methods). The question then arises as to which of the five methods used in the sensitivity analysis could be recommended for accounting for biodiversity loss. As previously stated, it is important to select the right method in relation to the specific scope of the study; hence, it may not be possible to provide a general recommendation for a preferred method. We note, however, that land use LCIA models are complex and that their associated methodological reports may not be sufficiently detailed and transparent to support a well-informed choice. Moreover, considerable time is required to review these methods and to analyse the robustness of the flows and related characterisation factors they employ. Based on the analysis made in this paper, we suggest that Eco-Indicator 99 is the most comprehensive (although not the most recent) model, which may be applied in complement to the ILCD-recommended SOM model.

Our analysis also highlights three additional areas in which methodological improvement for land use LCIA should be achieved. A first improvement is establishing clearer connections between different indicators of land use impact, such as loss of organic carbon, reduction of species richness and loss of supplied ecosystem functions, is desirable. Secondly, more regional characterisation factors are recommended for use in Europe and worldwide. In current practice, different ecoregions within Europe are assigned the same characterisation factors for damage as a result of land transformation and/or occupation (i.e. only generalised characterisation factors are available). Moreover, these values are often applied in global assessments due to the lack of characterisation factors for other parts of the world. Thirdly, currently operational methods for the assessment of loss of biodiversity use vascular plants as surrogate species. These may not be representative of impacts for other taxa. There are, however, a number of newly developed land use models which provide better resolution in this regard (see, for example, those presented in the special issue coordinated by Köllner and Geyer (2013)). These new models are not yet available for use in commercial LCA software, implying that they are not yet widely used in current practice. It is hence recommended to make these improved, more recent, methods operational. A detailed analysis of these more recently developed models in the context of buildings is identified as an important future research step in order to investigate if any of these is relevant and more appropriate than an existing model already operational. Recently published approaches such as de Baan et al.
(2013) following the work developed by Souza (2010) take into account species extinction as a distinction between reversible and irreversible (permanent) impacts. Both works include a wider range of taxonomic groups, such as mammals, reptiles, birds and amphibians, from the WildFinder database (WWF 2013). Moreover, Souza (2010) included a weighting scheme for taking into account the threat status of species as a measure of biodiversity loss. Ecoregion scarcity and vulnerability (habitat loss, fragmentation, degradation and conversion) were considered as a measure of impacts on species habitats.

Looking beyond the land use impact category, our analysis also underscores significant current deficiencies related to accounting for resources in LCIA models. This includes the non-accounting for depletion of biotic resources, such as timber, and abiotic surface minerals (i.e. sand, clay and gravel), in the majority of current operational impact assessment methods. But also, soil itself, an important and finite resource, is usually not taken into account in life cycle impact assessments (other than indirectly via the indication of land area lost or by changes in SOM).

Acknowledgments The contribution of the colleagues within the OVAM-MMG project are acknowledged. More specifically, we thank Wim Debacker, Carolin Spirinckx, Karolien Peeters, Leo De Nocker (VITO), An Janssen, Laetitia Delem, Johan Van Dessel (BBRI) and Damien Trigaux, Frank De Troyer (KU Leuven). The contribution from D.M. Souza has been supported by the SoilTrEC (Soil Transformations in European Catchments), Grant Agreement no. 244118, funded by the European Commission under the 7th Framework Programme. We would like to thank Nathan Pelletier for his comments on this paper.

\section{References}

AAVV (2005) Besluit van de Vlaamse Regering van 11 maart 2005 tot vaststelling van de eisen op het vlak van de energieprestaties en het binnenklimaat van gebouwen. Belgisch Staatsblad, Brussels, Belgium

AFNOR (2004) NFP 01-010 Qualité environnementale des produits de construction-Déclaration environnementale et sanitaire des produits de construction

Allacker K (2010) Sustainable building: the development of an evaluation method. Dissertation Department of Architecture. Katholieke Universiteit Leuven, Belgium. https://irias.kuleuven.be/handle/ 123456789/267749. Accessed January 2012

Allacker K, De Troyer F, Trigaux D, Geerken T, Debacker W, Spirinckx C, Van Dessel J, Janssen A, Delem L, Putzeys K (2011) Sustainability, financial and quality evaluation of dwelling typesSuFiQuaD: Final Report, the Belgian Science Policy, Brussels

Allacker K (2012) Environmental and economic optimisation of the floor on grade in residential buildings. Int J Life Cycle Assess 17:813827

Asif M, Muneer T, Kelley R (2007) Life cycle assessment: a case study of a dwelling home in Scotland. Build Environ 42:1391-1394

Bare J, Hofstetter P, Pennington D, Haes HU (2000) Midpoints versus endpoints: the sacrifices and benefits. Int J Life Cycle Ass 5:319 326. doi:10.1007/BF02978665 
Bluemer M, Kylaekorpi L (1998) MALVA, the biotope method. Vattenfall

BRE (2007). Methodology for environmental profiles of construction products - product category rules for type III environmental product declaration of construction products (Draft August 2007). www.bre. co.uk (accessed April 2013)

BRE (2013) BREEAM - the world's leading design and assessment method for sustainable buildings. www.breeam.org/ (accessed April 2013)

CEN (2011) CEN TC350EN 15978 - sustainability of construction works - assessment of environmental performance of buildingscalculation method

CEN (2012) CEN TC350 EN 15804 - sustainability of construction works - environmental product declarations - core rules for the product category of construction products

De Baan L, Mutel CL, Curran M, Hellweg S, Köllner T (2013) Land use in life cycle assessment: global characterization factors based on regional and global potential species extinction. Environ Sci Technol 47:9281-9290

De Schryver A, Goedkoop M (2009) A life cycle impact assessment method which comprises harmonised category indicators at the midpoint and the endpoint level. In: Goedkoop M, Heijungs R, Huijbregts M, De Schryver A, Struijs J, Zelm Rv (eds), ReCiPe 2008. Pré-Consultants, Amersfoort, pp 98-115

DGNB GmBH (2013) “The DGNB system”. www.dgnb-system.de (accessed April 2013)

EEA (2010) SOER 2010: the European environment - state and outlook 2010: land use. European Environmental Agency (EEA), Publications Office of the European Environmental Agency, Denmark

European Commission-EC (2006) Communication from the European Commission. Thematic Strategy for Soil Protection $(\mathrm{COM}(2006) 231)$

EC (2009) European Parliament and of the Council Directive 2009/28/EC of 23 April 2009 on the promotion of the use of energy from renewable sources and amending and subsequently repealing Directives 2001/77/EC and 2003/30/EC

EC (2010a) Communication from the European Commission. EU's Europe 2020 Strategy for smart, sustainable and inclusive growth (COM(2010)2020)

EC (2010b) European Parliament and Council Directive 2010/31/EU of 19 May 2010 on the energy performance of buildings (recast). Official Journal of the European Union, L153, 13-35

EC (2011a) Communication from the European Commission. Resource Efficient Europe (COM(2011)21)

EC (2011b) Communication from the European Commission. Our life insurance, our natural capital: an EU biodiversity strategy to 2020 (COM(2011)244)

EC (2012) Communication from the European Commission. Innovating for sustainable growth: a bio-economy for Europe (COM (2012)60)

EC-JRC (2011) International Reference Life Cycle Data System (ILCD) Handbook-recommendations for life cycle assessment in the European context-based on existing environmental impact assessment models and factors. ISBN 978-92-79-17451-3, doi: 10.278/ 33030. European Commission - Joint Research Centre. Publications Office of the European Union, Luxembourg

Ecoinvent (2012) www.ecoinvent.org. (Accessed August 2012)

Feist W, Schnieders J, Loga T, Bisanz C, Mangold D, Ebel W (2001) Energiebilanzen mit dem Passivhaus Projektierungs Paket. Passivhaus Institut, Darmstadt, Germany

Finnveden G, Hauschild MZ, Ekvall T, Guinee J, Heijungs R, Hellweg S, Koehler A, Pennington D, Suh S (2009) Recent developments in life cycle assessment. J Environ Manage 91:1-21

Frischknecht R, Steiner R, Jungbluth N (2008) The ecological scarcity method-eco-factors 2006. A method for impact assessment in
LCA. Environmental studies no 0906. Federal Office for the Environment (FOEN), Bern

Goedkoop M, Heijungs R, Huijbregts M, De Schryver A, Struijs J, van Zelm R (2012) ReCiPe 2008: a life cycle impact assessment method which comprise harmonised category indicators at the midpoint and the endpoint level. First edition report I: characterization. Ruimte en Milieu Ministerie van Volkshuisvesting Ruimtelijke Ordening en Milieubeheer, The Netherlands, p 126

Goedkoop M, Spriensma R (2000) The Eco-indicator 99: a damage oriented method for life cycle impact assessment methodology. Ministry of VROM, The Hague, Netherlands

Helgeson JF, Lippiatt BC (2009) Multidisciplinary life cycle metrics and tools for green buildings. Integrated Environ Assess Manag 5:390 398

Humbert S, De Schryver A, Bengoa X, Margni M, Jolliet O (2012) Impact 2002+: user guide draft for version Q2.21. Quantis, Switzerland

Jolliet O, Margni M, Charles R, Humbert S, Payet J, Rebitzer G, Rosenbaum R (2003) IMPACT 2002+: a new life cycle impact assessment methodology. Int J Life Cycle Ass 8:324-30

Jones A, Panagos P, Barcelo S, Bouraoui F, Bosco C, Dewitte O, Gardi C, Erhard M, Hervás J, Hiederer R, Jeffery S, Lükewille A, Marmo L, Montanarella L, Olazábal C, Petersen JE, Penizek V, Strassburger T, Tóth G, Van Den Eeckhaut M, Van Liedekerke M, Verheijen F, Viestova E, Yigini Y (2012) The state of soil in Europe - a contribution of the JRC to the EEA Environment State and Outlook Report-SOER 2010. Publications Office of the European Union, Luxembourg, p 76

Köllner T (2003) Land use in product life cycles and ecosystem quality. Frankfurt am Main, Peter Lang

Köllner T, Baan L, Beck T, Brandão M, Civit B, Goedkoop M, Margni M, Milà i Canals L, Mueller-Wenk R, Weidema B, Wittstock B (2013a) Principles for life cycle inventories of land use on global scale. Int $\mathrm{J}$ Life Cycle Assess 18:1203-1215

Köllner T, Baan L, Beck T, Brandão M, Civit B, Margni M, Milà i Canals L, Saad R, Souza DM, Mueller-Wenk R (2013b) UNEP-SETAC guideline on global land use impact assessment on biodiversity and ecosystem services in LCA. Int J Life Cycle Assess 18:1188-1202

Köllner T, Geyer R (2013) Global land use impact assessment on biodiversity and ecosystem services in LCA. Int J Life Cycle Assess 18: $1185-1187$

Michelsen O (2008) Assessment of land use impact on biodiversity. Int J Life Cycle Assess 13:22-31

Milà i Canals L, Bauer C, Depestele J, Dubreuil A, Freiermuth Knuchel R, Gaillard G, Michelsen O, Mueller-Wenk R, Rydgren (2007) Key elements in a framework for land use impact assessment within LCA. Int J Life Cycle Assess 12:5-15

Müller-Wenk R (1998) Land use the main threat to species: how to include land use in LCA. Universität St. Gallen, St. Gallen, IWÖ Diskussionsbeitrag

Nemry F, Uihlein A, Colodel CM, Wetzel C, Braune A, Wittstock B, Hasan I, Kreissig J, Gallon N, Niemeier S, Frech Y (2010) Options to reduce the environmental impacts of residential buildings in the European Union-potential and costs. Energ Buildings 42:976-84

NEN (2004) NEN 8006: Milieugegevens van bouwmaterialen, bouwproducten en bouwelementen voor opname in een milieuverklaring - Bepalingsmethode volgens de levenscyclusanalysemethode (LCA) (translated title: Environmental data of building materials, building products and building elements for application in environmental product declarations - assessment according to the life cycle assessment (LCA) methodology. Delft: NEN Uitgeverij

Passivhaus Institut (2006) Passiefhuis-Projectpakket 2003. Passiefhuis Platform vzw, Benelux, Berchem, Belgium

Pre Consultants (2012) SimaPro. Pre Consultants, Netherlands http:// www.pre-sustainability.com/content/simapro-lca-software/ 
Saad R, Köllner T, Margni M (2013) Land use impacts on freshwater regulation, erosion regulation, and water purification: a spatial approach for a global scale level. Int J Life Cycle Assess 18:1253-64

Souza DM, Flynn DB, DeClerck F, Rosenbaum R, Melo Lisboa H, Köllner T (2013) Land use impacts on biodiversity in LCA: proposal of characterization factors based on functional diversity. Int J Life Cycle Assess 18:1231-42

Souza DM (2010) Proposta de um modelo de caracterizacao de impactos do uso da terra, segundo indicadores de biodiversidade, em AICV: calculo de fatores de caracterizacao para ecorregioes brasileiras. $\mathrm{PhD}$ Dissertation Programa de Pos-Graduacao em Engenharia Ambiental Florianopolis: Universidade Federal de Santa Catarina; $\mathrm{p} 309$

Steen B (1999) A systematic approach to environmental priority strategies in product development (EPS). Chalmers University of Technology, Göteborg, CPM Report

USGBC (2013) LEED_Leadership in Energy and Environmental Design. www.usgbc.org/leed (accessed April 2013)
Valderrama C, Granados R, Cortina JL, Gasol CM, Guillem M, Josa A (2012) Implementation of best available techniques in cement manufacturing: a life-cycle assessment study. J Cleaner Prod 25: $60-67$

VEA (2012) www.energiesparen.be/epb/welkeeisen (Accessed August 2012)

Weidema BP, Lindeijer E (2001) Physical impacts of land use in product life cycle assessment: final report of the EURENVIRONLCAGAPS sub-project on land use, EUREKA Project EU-1296, Lyngby

Werner F, Richter K (2007) Wooden building products in comparative LCA. Int J Life Cycle Assess 12:470-479

WWF (2013) Wildfinder. Available at www.worldwildlife.org/pages/ wildfinder. Accessed Dec 2013

Zabalza Bribián I, Aranda Usón A, Scarpellini S (2009) Life cycle assessment in buildings: state-of-the-art and simplified LCA methodology as a complement for building certification. Build Environ 44:2510-2520 